\title{
Allergy Unit per Milliliter
}

National Cancer Institute

\section{Source}

National Cancer Institute. Allergy Unit per Milliliter. NCI Thesaurus. Code C70504.

Unit of measure of potency of allergenic product expressed as a number of allergy units per one milliliter of formulation. 